University of South Florida

DIGITAL COMMONS

Digital Commons @ University of

@ UNIVERSITY OF SOUTH FLORIDA

South Florida

School of Geosciences Faculty and Staff

Publications

$5-2017$

\title{
The 2016 North Atlantic Hurricane Season: A Season of Extremes
}

Jennifer Collins

University of South Florida, collinsjm@usf.edu

David R. Roache

University of South Florida

Follow this and additional works at: https://digitalcommons.usf.edu/geo_facpub

Part of the Earth Sciences Commons

\section{Scholar Commons Citation}

Collins, Jennifer and Roache, David R., "The 2016 North Atlantic Hurricane Season: A Season of Extremes" (2017). School of Geosciences Faculty and Staff Publications. 1399.

https://digitalcommons.usf.edu/geo_facpub/1399

This Article is brought to you for free and open access by the School of Geosciences at Digital Commons @ University of South Florida. It has been accepted for inclusion in School of Geosciences Faculty and Staff Publications by an authorized administrator of Digital Commons @ University of South Florida. For more information, please contact digitalcommons@usf.edu. 


\section{Geophysical Research Letters}

\section{RESEARCH LETTER}

10.1002/2017GL073390

Key Points:

- In 2016, not many storms formed in the main development region. The very low relative humidity in this area largely accounts for this

- The 2016 season experienced the North Atlantic's first Cat 5 in almost a decade; this is the longest stretch without a Cat 5 since 1950

- Hurricane Matthew formed in October when relative vorticity, pressure, precipitable water, and relative humidity were all favorable for development

Correspondence to:

J. M. Collins,

collinsjm@usf.edu

\section{Citation:}

Collins, J. M., and D. R. Roache (2017), The 2016 North Atlantic hurricane season: A season of extremes, Geophys. Res. Lett., 44, 5071-5077, doi:10.1002/2017GL073390.

Received 13 MAR 2017 Accepted 20 APR 2017 Accepted article online 3 MAY 2017 Published online 21 MAY 2017

\section{The 2016 North Atlantic hurricane season: A season of extremes}

\author{
Jennifer M. Collins ${ }^{1}$ (D) and David R. Roache' ${ }^{1}$ (D) \\ ${ }^{1}$ School of Geosciences, University of South Florida, Tampa, Florida, USA
}

Abstract The 2016 North Atlantic hurricane season had an early start with a rare and powerful storm for January impacting the Azores at hurricane force. Likewise, the end of season heralded Otto which was record breaking in location and intensity being a high-end Category 2 storm at landfall over southern central America in late November. We show that high precipitable water, positive relative vorticity, and low sea level pressure allowed for conducive conditions. During the season, few storms occurred in the main development region. While some environmental conditions were conducive for formation there (such as precipitable water, relative vorticity, and shear), the midlevel relative humidity was too low there for most of the season, presenting very dry conditions in that level of the atmosphere. We further find that the October peak in the accumulated cyclone energy was related to environmentally conducive conditions with positive relative humidity, precipitable water, relative humidity, and low values of sea level pressure. Overall 2016 was notable for a series of extremes, some rarely, and a few never before observed in the Atlantic basin, a potential harbinger of seasons to come in the face of ongoing global climate change.

\section{Introduction}

Tropical cyclones which form in the North Atlantic basin, with many having a west-north-west track toward the United States, receive considerable attention not only from the public but also from the research community. With the damage and destruction hurricanes inflict on the eastern sea-board of the United States in particular, Mexico and Islands, the North Atlantic hurricane basin is one of the most widely studied.

Tropical cyclone activity varies considerably from year to year. Several authors have discussed factors which they note are important for tropical cyclone formation. Palmén [1948] was the first to emphasize the importance for tropical cyclone development of a critical sea surface temperature, which he related to atmospheric instability. Likewise, the importance of instability was also noted by Namias [1954]. Gray [1979] developed a list of six local environmental variables which he noted affects seasonal tropical cyclone development. This list included both dynamic and thermodynamic factors. Others have provided additional insight into factors which affect tropical cyclone formation including Knaff [1997], Lupo et al. [2008], and Elsner and Kara [1999] who each highlighted the nonlocal relationship between El Niño-Southern Oscillation (ENSO) and North Atlantic tropical cyclone activity. Evan et al. [2006] further identified African dust outbreaks as a factor which limits Atlantic tropical cyclone activity due to their association with low atmospheric moisture, high vertical wind shear, and stability.

Since these works, specific hurricane seasons have been studied, where a discussion is given of the nuances of that season. For instance, Collins and Roache [2010] examined the 2009 North Atlantic hurricane season noting when considering overall hurricane activity: it was below normal, and there was a late start to the season, which is in contrast to the 2016 season. Collins and Roache [2010] and Collins and Roache [2011] also note sharp intraseasonal variability during the 2009 hurricane season for the North Atlantic and eastern North Pacific, respectively. More recently, Collins et al. [2016] and Murakami et al. [2017] examined the 2015 hurricane season in the eastern North Pacific and note the relationship of the strong El Niño and the season of extremes in terms of several environmental variables.

The purpose of this paper is to show why the 2016 North Atlantic hurricane season was unique. This paper details the early start to the hurricane season, the record-breaking location and intensity of events at the end of the season, the first Category 5 hurricane in almost a decade, the lack of storms in the main development region (MDR: $10^{\circ} \mathrm{N}$ to $20^{\circ} \mathrm{N}$ and $20^{\circ} \mathrm{W}$ to $60^{\circ} \mathrm{W}$ [Saunders and Harris, [1997]), the first observed season with two Category 4 or stronger storms in the month of October, the first observed season with two 
Table 1. 2016 Tropical Cyclone Activity by Storm ${ }^{a}$

\begin{tabular}{lccccccc} 
Name & NS & NSD & H & HD & IH & IHD & ACE \\
\hline 2016 & 15 & 72.00 & 7 & 25.75 & 3 & 9.75 & 128.7025 \\
Alex & 1 & 2.25 & 1 & 1.00 & 0 & 0.00 & 3.5700 \\
Bonnie & 1 & 1.50 & 0 & 0.00 & 0 & 0.00 & 0.7725 \\
Charlie & 1 & 1.50 & 0 & 0.00 & 0 & 0.00 & 1.1350 \\
Danielle & 1 & 0.50 & 0 & 0.00 & 0 & 0.00 & 0.3200 \\
Earl & 1 & 4.00 & 1 & 0.50 & 0 & 0.00 & 3.7950 \\
Fiona & 1 & 4.25 & 0 & 0.00 & 0 & 0.00 & 2.4250 \\
Gaston & 1 & 11.25 & 1 & 5.50 & 1 & 1.50 & 24.1625 \\
Hermine & 1 & 3.00 & 1 & 0.75 & 0 & 0.00 & 3.7450 \\
lan & 1 & 3.00 & 0 & 0.00 & 0 & 0.00 & 2.1000 \\
Julia & 1 & 1.25 & 0 & 0.00 & 0 & 0.00 & 0.6125 \\
Karl & 1 & 8.00 & 0 & 0.00 & 0 & 0.00 & 5.7250 \\
Lisa & 1 & 3.50 & 0 & 0.00 & 0 & 0.00 & 2.2600 \\
Matthew & 1 & 11.00 & 1 & 9.75 & 1 & 7.25 & 47.6925 \\
Nicole & 1 & 13.00 & 1 & 6.25 & 1 & 1.00 & 23.6550 \\
Otto & 1 & 4.00 & 1 & 2.00 & 0 & 0.00 & 6.7325 \\
\hline \multicolumn{1}{c}{ a } & & &
\end{tabular}

${ }^{a}$ Named storms (NS), named storm days (NSD), hurricanes (H), hurricane days (HD), intense hurricanes (IH), intense hurricane days (IHD), and accumulated cyclone energy (ACE). 1 denotes it reached the intensity of the tropical cyclone category; 0 denotes it did not. storms striking both Bermuda and the Azores, and the large-scale environmental factors associated with the variations in tropical cyclone activity throughout the North Atlantic for the 2016 season.

\section{Data}

Tropical cyclone records from 1900 to 2015 were obtained from the HURricane DATa second generation database [Landsea and Franklin, 2013] (available online at http://www.aoml.noaa.gov/hrd/ hurdat/Data_Storm.html). This database contains tropical cyclone location and intensity information available at six-hourly intervals. For 2016 data, we utilized operational best track data generated

by the National Hurricane Center as archived by the University Corporation for Atmospheric Research located online at http://www.ral.ucar.edu/hurricanes/repository/data/bdecks_open/. We use tropical cyclone numbers and the accumulated cyclone energy (ACE) to compare the seasons and activity within the season. Bell et al. [2000] define ACE as the sum of the squares of the maximum sustained surface wind speed (knots) measured every $6 \mathrm{~h}$ for all named systems while they are at least tropical storm strength and not extratropical in phase.

$$
\mathrm{ACE}=10^{-4} \Sigma v^{2} \max
$$

where $v_{\max }$ is estimated sustained wind speed in knots

We utilize the National Centers for Environmental Prediction (NCEP)/National Center for Atmospheric Research (NCAR) reanalysis to analyze atmospheric and oceanic large-scale parameters. The data are available from 1948 to Present [Kalnay et al., 1996] and can be downloaded from https://www.esrl.noaa.gov/ psd/data/gridded/data.ncep.reanalysis.html\#detail. The global data are available in the NCEP/NCAR reanalysis for six-hourly and monthly time resolution, for several vertical levels (the number of which depends on the examined variable), and on a $2.5^{\circ} \times 2.5^{\circ}$ latitude-longitude grid. The comprehensive observational database and the period covered are two characteristics which make the NCEP/NCAR reanalysis project unique, making the data suitable for this study. Collins and Mason [2000] and Kalnay et al. [1996] have addressed confidence in these data. All atmospheric fields obtained from NCEP/NCAR reanalysis are ranked from 1948 to 2016.

Mean climatological statistics for all data sets were calculated for the 1981-2010 period. The months August to October are used to average the monthly environmental data as these correspond to the peak tropical cyclone activity in the North Atlantic. The rank of each variable is determined from the entire NCEP/NCAR reanalysis period of 1948-2016, for the purpose of comparing 2016 values to previous seasons. Rank order is defined by anomaly values which are favorable to tropical cyclone activity-hence, 1 would be the season most conducive for tropical cyclone activity (for example, negative anomalies for vertical wind shear and positive anomalies for relative humidity) and 69 the least conducive for tropical activity for atmospheric parameters.

\section{Results}

\subsection{Analysis of the 2016 North Atlantic Season: Tropical Cyclone Activity}

Tables 1 and 2 show tropical cyclone activity in 2016, by storm and by month, respectively. The 2016 season was slightly above-average overall when considering ACE (129). There were 15 tropical storms, 7 hurricanes, 
Table 2. Tropical Cyclone Activity by Month ${ }^{\mathrm{a}}$

\begin{tabular}{lccccccc} 
Month & NS & NSD & H & HD & IH & IHD & ACE \\
\hline 2016 & 15 & 72.00 & 7 & 25.75 & 3 & 9.75 & 128.7025 \\
January & 1 & 2.25 & 1 & 1.00 & 0 & 0.00 & 3.5700 \\
May & 1 & 0.75 & 0 & 0.00 & 0 & 0.00 & 0.4050 \\
June & 3 & 2.75 & 0 & 0.00 & 0 & 0.00 & 1.8225 \\
July & 0 & 0.00 & 0 & 0.00 & 0 & 0.00 & 0.0000 \\
August & 4 & 17.50 & 2 & 4.75 & 1 & 1.50 & 26.7025 \\
September & 7 & 23.25 & 3 & 3.25 & 1 & 0.25 & 22.9450 \\
October & 2 & 21.50 & 2 & 14.75 & 2 & 8.00 & 66.5250 \\
November & 1 & 4.00 & 1 & 2.00 & 0 & 0.00 & 6.7325 \\
\hline
\end{tabular}

${ }^{\mathrm{a}}$ Named storms (NS), named storm days (NSD), hurricanes (H), hurricane days (HD), intense hurricanes (IH), intense hurricane days (IHD), and accumulated cyclone energy (ACE). Note that monthly storm count statistics are not summative to yearly totals due to overlapping of tropical cyclones across consecutive months; duration and ACE statistics are summative. and 3 intense hurricanes (see Figure 1). The averages for the period of 1981-2010 are 11.8, 6.4, and 2.7, respectively. As can be seen, one hurricane (Alex) occurred in January. As shown in Figure 1, this storm impacted the Azores at hurricane force. Later in the season, Gaston also impacted the Azores at tropical storm strength. Interestingly, this is the first observed season where both the Azores and Bermuda were impacted by two tropical cyclones (Bermuda: Karl and Nicole). While some tropical storms occurred in

May and June, no hurricanes formed again until August. As expected given that these months are the peak of activity in the North Atlantic, August through October had the most activity, generating $90 \%$ of the total ACE for the 2016 season. All the intense hurricanes of the season occurred in these peak months. It is notable that the month of October alone generated the most ACE for the season (over $50 \%$ of the season's total), and for the first time, October saw two tropical cyclones of Category 4 or higher intensity in the North Atlantic basin. Furthermore, if we examine October hurricanes passing near Bermuda, Nicole was only the fifth to do so since 1950. Activity ended in November, with Hurricane Otto making a historically late southern landfall and becoming one of the few tropical cyclones to cross from the North Atlantic into the eastern North Pacific basins.

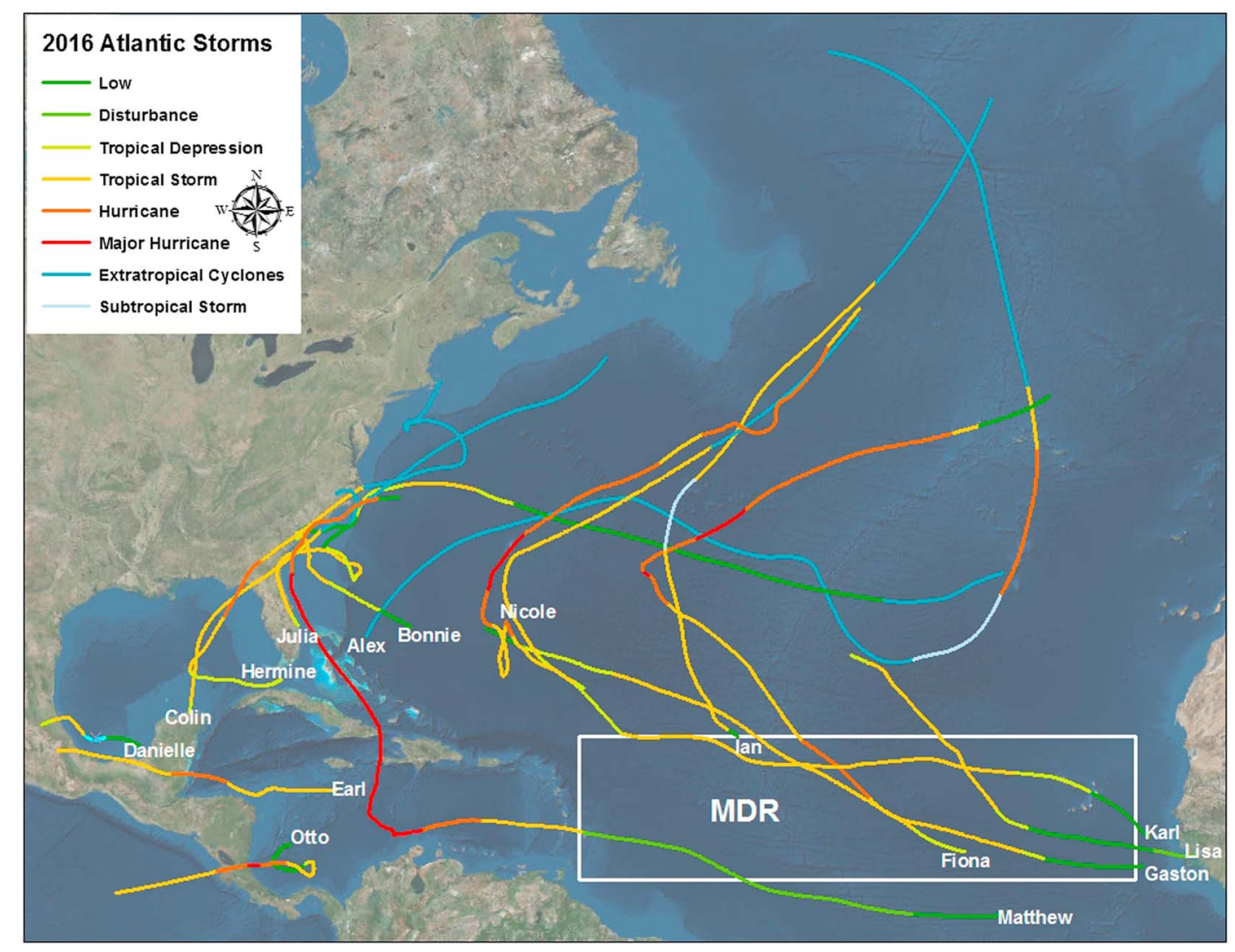

Figure 1. 2016 storm tracks. 
Table 3. Top 5 Years With the Longest Duration of the Tropical Cyclone Season

\begin{tabular}{ccccc} 
Season & Begin & End & Duration & Rank \\
\hline 1951 & $1 / 4$ & $12 / 11$ & 342 & 1 \\
2016 & $1 / 13$ & $11 / 25$ & 318 & 2 \\
1938 & $1 / 3$ & $11 / 9$ & 311 & 3 \\
1955 & $1 / 1$ & $10 / 19$ & 292 & 4 \\
1978 & $1 / 19$ & $11 / 1$ & 287 & 5 \\
\hline
\end{tabular}

Matthew). The length of this quiet stretch (in terms of Category 5 storms) just prior to the 2016 season is the longest in the satellite era and the second longest ever observed in the basin since the first known Category 5 in 1924.

\subsection{Analysis of the $\mathbf{2 0 1 6}$ North Atlantic Season: Environmental Conditions}

The 2016 hurricane season started during a very strong El Niño event, with neutral ENSO conditions prevailing through much of the hurricane season, trending toward La Niña conditions. An examination of precipitable water, vertical wind shear, and relative vorticity in Figures $2 a-2 c$ shows that when considering these environmental variables, conditions were conducive in 2016 over the MDR of the North Atlantic. However,
(A) Precipitable Water

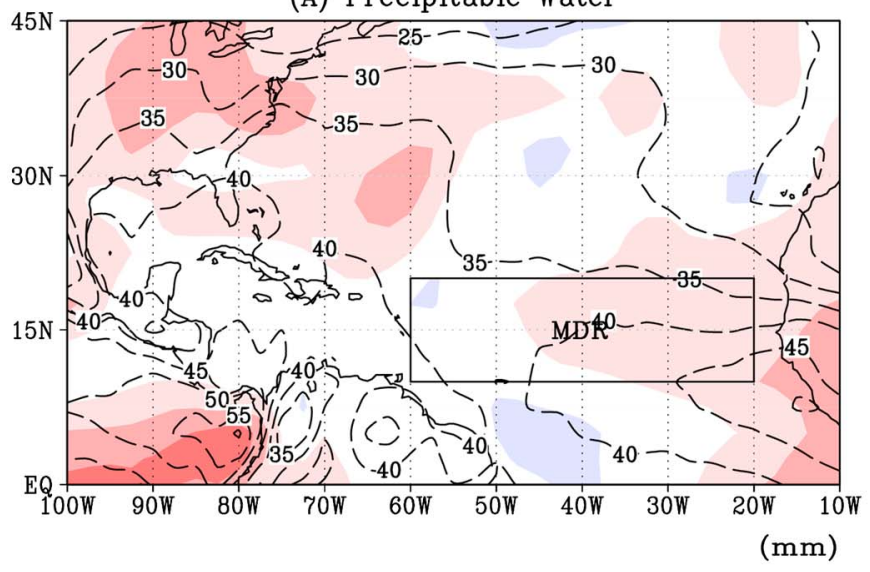

(C) Vertical Wind Shear

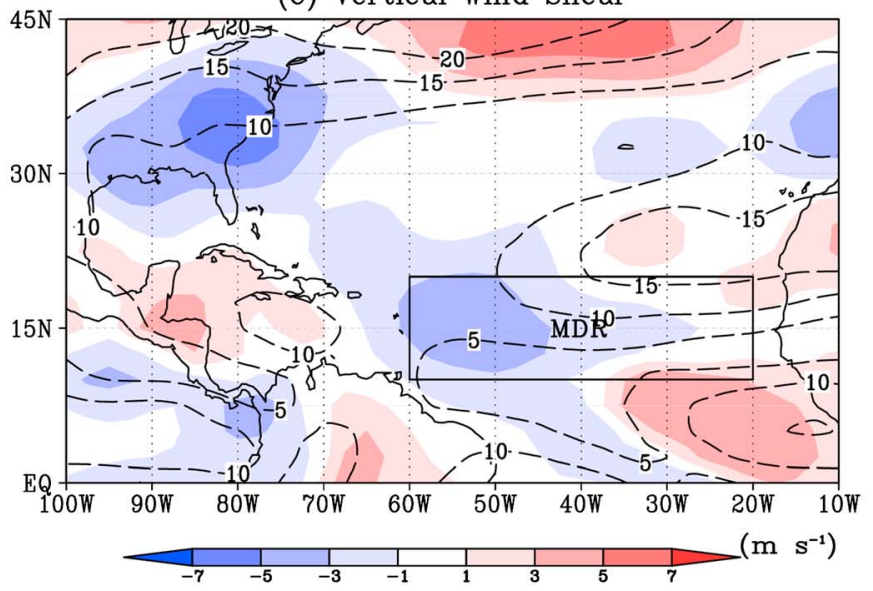

(B) Relative Vorticity

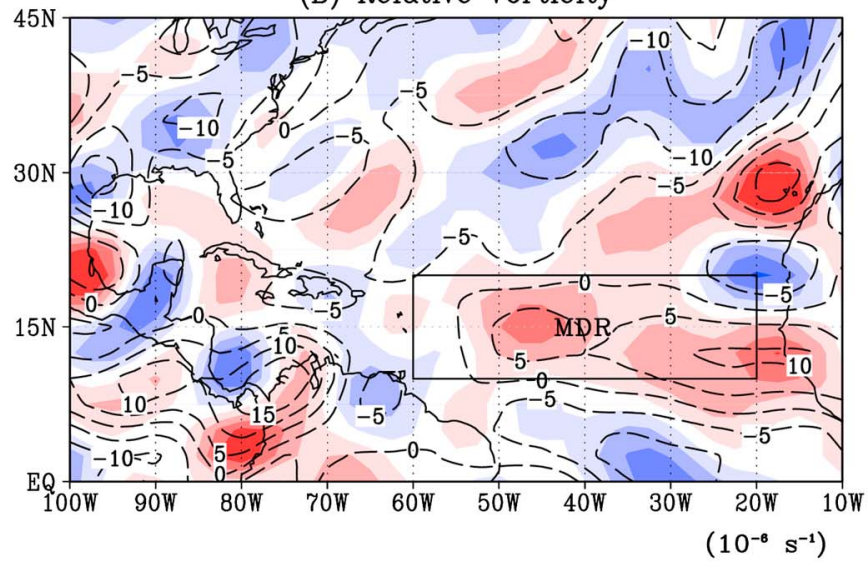

(D) Relative Humidity

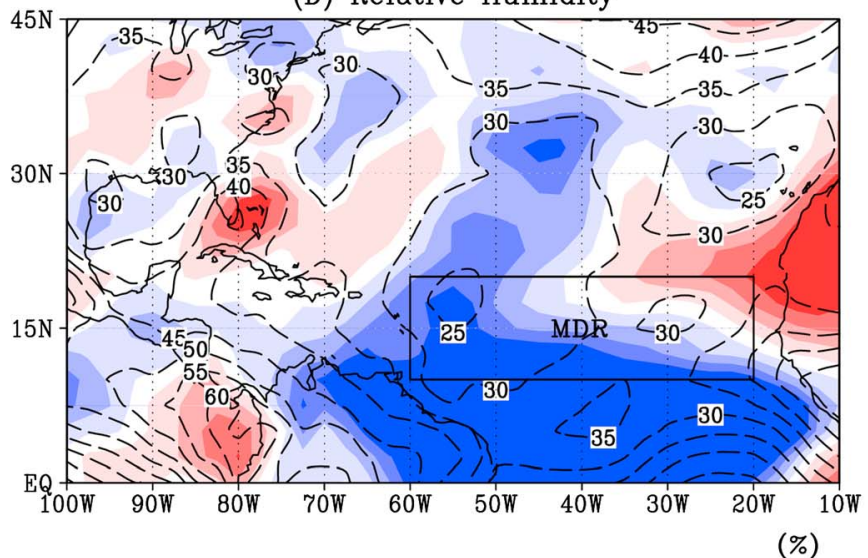

Figure 2. (a) August-October precipitable water means (contours) and anomalies (shading) in $\mathrm{mm}$. (b) August-October $850 \mathrm{hPa}$ vorticity means (contours) and anomalies (shading) in $10^{-6} \mathrm{~s}^{-1}$. (c) August-October $850 \mathrm{hPa}-200 \mathrm{hPa}$ vertical wind shear means (contours) and anomalies (shading) in $\mathrm{m} \mathrm{s}^{-1}$. (d) AugustOctober $500 \mathrm{hPa}$ relative humidity means (contours) and anomalies (shading) in \%. 
(A) JULY

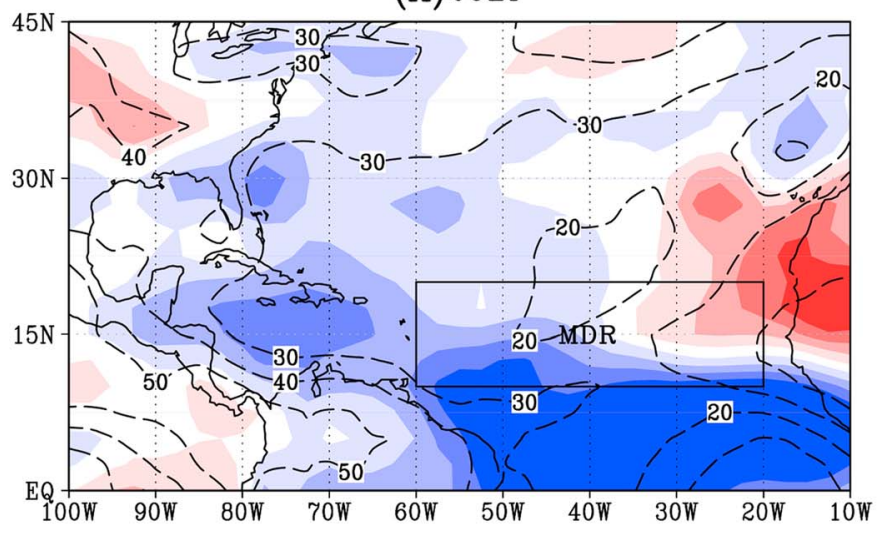

(C) SEPTEMBER

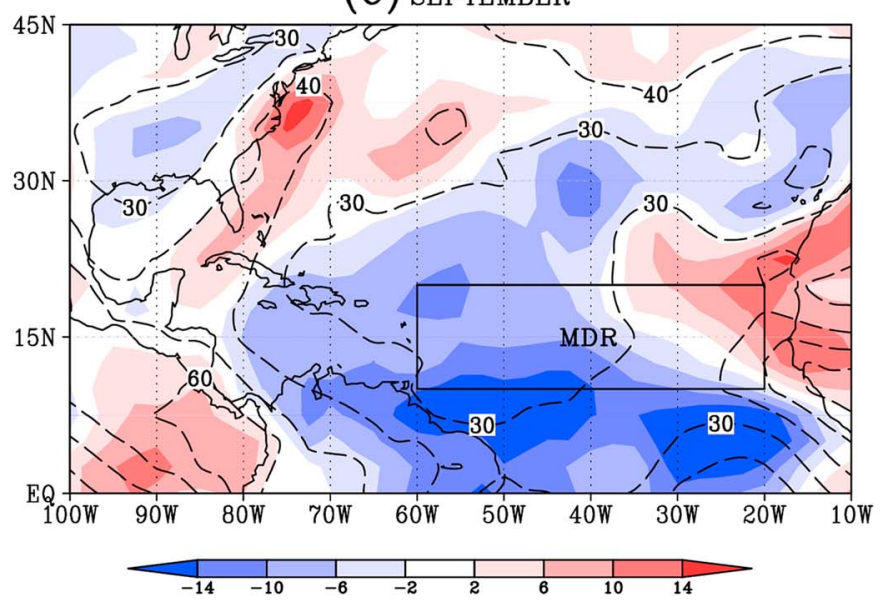

(B) AUGUST

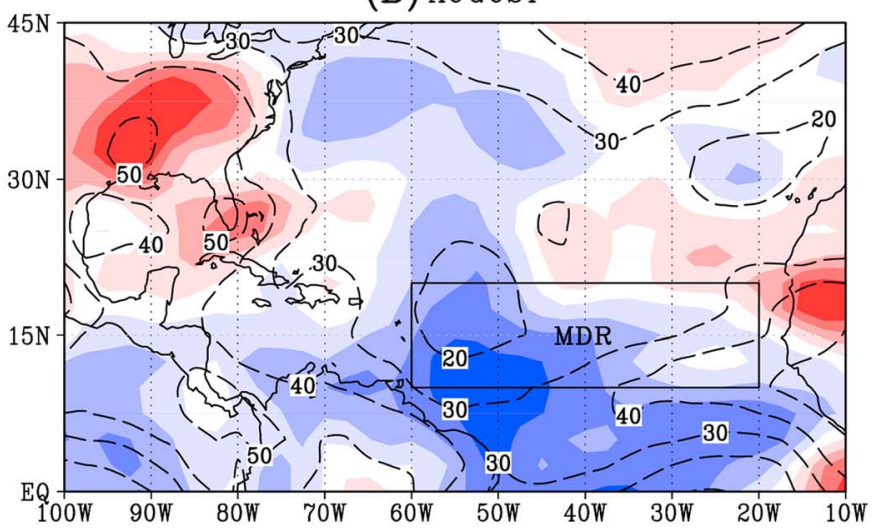

(D) OCTOBER

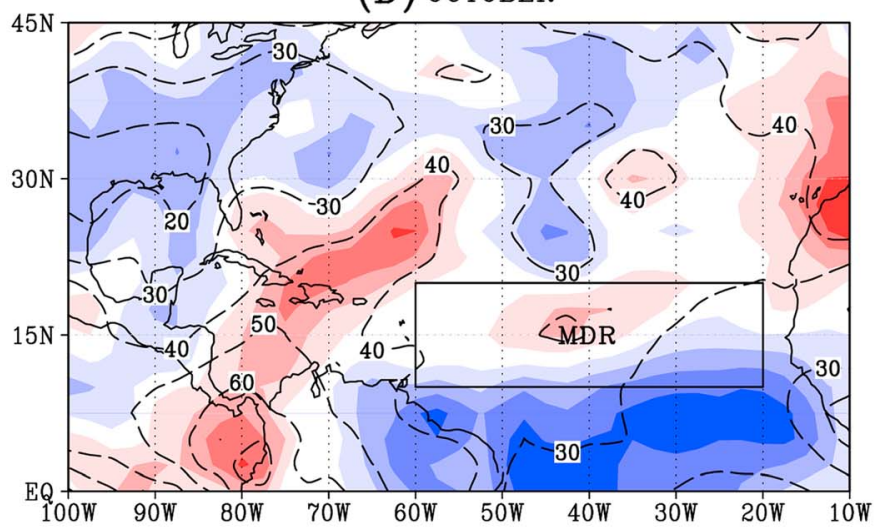

(\%)

Figure 3. $500 \mathrm{hPa}$ relative humidity by month.

an examination of relative humidity at $500 \mathrm{mb}$ (Figure $2 \mathrm{~d}$ ) reveals why very little activity was observed directly in the MDR. Conditions in this midlevel area were extremely dry. When one considers the rank of average relative humidity conditions in the MDR over the peak of the season, the 2016 season ranks as one of the least conducive on record, ranking 65 out of 69 . This explains why there is a lack of storms in the MDR (Figure 1).

Figure 3 shows how midlevel relative humidity changes throughout the season. As noted earlier, for much of the season, conditions in the MDR are not conducive to tropical cyclone development (Figures 3a-3c). However, Figure $3 \mathrm{~d}$ shows a dramatic change in relative humidity compared with the rest of the season, with October conditions being conducive for tropical cyclone development. This contributed to the high October activity as noted in Tables 1 and 2 and section 3.1. It is in this month when Hurricane Matthew formed, which caused death and destruction first in Haiti and then in the United States. Then, Hurricane Nicole formed soon after as the next storm of the season. This is the first time we had two hurricanes of Category 4 or greater intensity in the month of October. Furthermore, Nicole brushed Bermuda, and this is only the fifth hurricane ever to do so in the month of October.

\subsection{Intraseasonal Variability}

Collins and Roache [2011] have previously shown the influence of the Madden-Julian Oscillation (MJO) [Madden and Julian, 1971, 1994] on intraseasonal tropical cyclone formation in the eastern North Pacific. Klotzbach [2010] noted large differences in tropical cyclone activity in terms of frequency and intensity with regard to the phase of the MJO in the tropical Atlantic as well as the Gulf of Mexico and northwest Caribbean. 


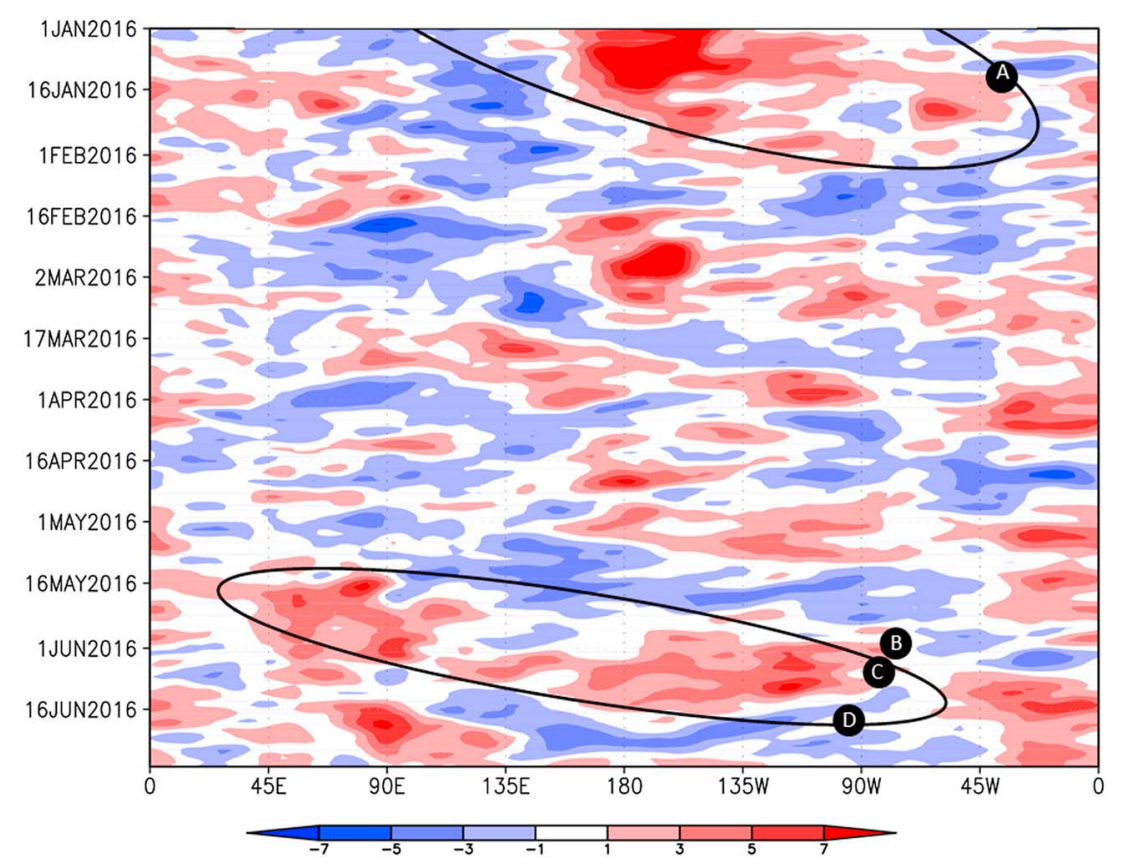

Figure 4. The $850 \mathrm{hPa}$ zonal wind anomaly $\left(\mathrm{m} \mathrm{s}^{-1}\right)$ Hovmöller diagram, averaged from $5^{\circ} \mathrm{S}$ to $5^{\circ} \mathrm{N}$. The black ellipses highlight eastward progression of the convectively active phase of the Madden-Julian Oscillation. Data obtained from the NCEP/NCAR reanalysis (anomalies based on the 1981-2010 climatology).

The MJO is resolved through $850 \mathrm{hPa}$ zonal wind anomalies. Figure 4 shows a Hovmöller diagram of the $850 \mathrm{mb}$ zonal wind averaged between $5^{\circ} \mathrm{S}$ and $5^{\circ} \mathrm{N}$. An active MJO period extends from the previous year into January (expressed by the eastward progression of positive anomalies indicating the convectively active phase of the MJO and highlighted with black ellipses), with a second active period late May/early June. The first ellipse corresponds with the development of early season storm, Hurricane Alex, and the second corresponds with the next three storms to form (Bonnie, Connie, and Danielle, all of tropical storm strength).

\section{Conclusions}

The focus of this article was on the tropical activity in the North Atlantic during 2016. The manuscript examines seasonal large-scale environmental conditions during the peak season, and it was shown that while several variables in the MDR were conducive to tropical cyclone development, midlevel relative humidity was not favorable to tropical cyclone development there, and this explains the lack of activity in the MDR during the peak season. Intraseasonal analysis of the MJO shows that its influence likely manifested in the early season January storm (Hurricane Alex) and the late May/June storms.

Several rare events occurred in 2016, with some never observed before in the Atlantic. In particular, we saw Hurricane Matthew become a Category 5 at the most southern latitude on record for the North Atlantic Ocean, with this storm later making landfall over Haiti (as a Category 4 hurricane) and the United States (as a Category 1 hurricane). It was also noted that in October, the midlevel relative humidity became conducive to formation, and this corresponds with the October peak in ACE, with the occurrence of Category 5 Hurricane Matthew and Category 4 Hurricane Nicole. Hurricane Nicole passed near Bermuda as a Category 3 and was only the fifth tropical cyclone to impact Bermuda in October since 1950. Furthermore, 2016 was the first observed season with two Category 4 or stronger storms in the month of October. In addition, this was the first observed season with two storms striking both Bermuda and the Azores. These extremes are perhaps a glimpse of future hurricane seasons in light of the ongoing global climate change. 
Acknowledgments

Figure 1 was created using ArcGIS software by Esri. ArcGIS and ArcMap" are the intellectual property of Esri and are used herein under license. Copyright $^{\circ}$ Esri. All rights reserved. For more information about Esri software, please visit www.esri.com. We thank Daniel Gessman and Chris Mehta for the creation of this figure. We thank the reviewers for their useful feedback. Data specific to this paper are available at: http://weathercenter.forest.usf.edu/ faculty/.

\section{References}

Bell, G. D., M. S. Halpert, R. C. Schnell, R. W. Higgins, J. Lawrimore, V. E. Kousky, R. Tinker, W. Thiaw, M. Chelliah, and A. Artusa (2000), Climate assessment for 1999, Bull. Am. Meteorol. Soc., 81, S1-S50.

Collins, J. M., and I. M. Mason (2000), Local environmental conditions related to seasonal tropical cyclone activity in the NE Pacific basin, Geophys. Res. Lett., 27(23), 3881-3884, doi:10.1029/2000GL011614.

Collins, J. M., and D. R. Roache (2010), The inactive 2009 hurricane season in the North Atlantic basin: An analysis of environmental conditions, Natl. Weather Dig., 34, 117-128.

Collins, J. M., and D. R. Roache (2011), The 2009 hurricane season in the eastern North Pacific basin: An analysis of environmental conditions, Mon. Weather Rev., 139, 1673-1682.

Collins, J. M., P. J. Klotzbach, R. N. Maue, D. R. Roache, E. S. Blake, C. H. Paxton, and C. A. Mehta (2016), The record-breaking 2015 hurricane season in the eastern North Pacific: An analysis of environmental conditions, Geophys. Res. Lett., 43, 9214-9224, doi:10.1002/ 2016GL070597.

Elsner, J. B., and A. B. Kara (1999), Hurricanes of the North Atlantic, pp. 240-272, Oxford Univ. Press, New York.

Evan, A. T., A. K. Heidinger, and P. Knippertz (2006), Analysis of winter dust activity off the coast of West Africa using a new $24-y e a r$ over-water advanced very high resolution radiometer satellite dust climatology, J. Geophys. Res., 111, D12210, doi:10.1029/2005JD006336.

Gray, W. M. (1979), Hurricanes: Their formation, structure and likely role in the tropical circulation, in Meteorology Over Tropical Oceans, edited by D. B. Shaw, pp. 155-218, R. Meteorol. Soc. Press, Bracknell, England.

Kalnay, E., et al. (1996), The NCEP/NCAR 40-year reanalysis project, Bull. Am. Meteorol. Soc., 77, 437-470.

Klotzbach, P. J. (2010), On the Madden-Julian Oscillation-Atlantic hurricane relationship, J. Clim., 23, 282-293.

Knaff, J. A. (1997), Implications of summertime sea level pressure anomalies in the tropical Atlantic region, J. Clim., 10, 789-804.

Landsea, C. W., and J. L. Franklin (2013), Atlantic hurricane database uncertainty and presentation of a new database format, Mon. Weather Rev., 141, 3576-3592, doi:10.1175/MWR-D-12-00254.1.

Lupo, A. R., T. K. Latham, T. Magill, J. V. Clark, C. J. Melick, and P. S. Market (2008), The interannual variability of hurricane activity in the Atlantic and East Pacific regions, Natl. Weather Dig., 32(2), 119-133.

Madden, R. A and P. R. Julian (1971), Detection of a 40-50 day oscillation in the zonal wind in the tropical Pacific, J. Atmos. Sci, 28, 702-708. Madden, R. A., and P. R. Julian (1994), Observations of the 40-50-day tropical oscillation-A review, Mon. Weather Rev., $122,814-837$.

Murakami, H., et al. (2017), Dominant role of subtropical Pacific warming in extreme eastern Pacific hurricane seasons: 2015 and the future, J. Clim., 30, 243-264.

Namias, J. (1954), Long range factors affecting the genesis and paths of tropical cyclones, in Proc. UNESCO Symp. on Typhoons, pp. 213-219, UNESCO, Tokyo, Japan.

Palmén, E. (1948), On the formation and structure of tropical hurricanes, Geophysica, 3, 26-38.

Saunders, M. A., and A. R. Harris (1997), Statistical evidence links exceptional 1995 Atlantic hurricane season to record sea warming Geophys. Res. Lett., 24, 1255-1258, doi:10.1029/97GL01164. 